\title{
Excitatory Effects of the Puberty-Initiating Peptide Kisspeptin and Group I Metabotropic Glutamate Receptor Agonists Differentiate Two Distinct Subpopulations of Gonadotropin-Releasing Hormone Neurons
}

\author{
Iryna Dumalska, ${ }^{1}$ Min Wu, ${ }^{1}$ Elena Morozova, ${ }^{1}$ Rongjian Liu, ${ }^{1}$ Anthony van den Pol, ${ }^{2}$ and Meenakshi Alreja ${ }^{1,3}$ \\ Departments of ${ }^{1}$ Psychiatry, ${ }^{2}$ Neurosurgery, and ${ }^{3}$ Neurobiology, Yale University School of Medicine and the Ribicoff Research Facilities, Connecticut \\ Mental Health Center, New Haven, Connecticut 06508
}

\begin{abstract}
Activation of the G-protein-coupled receptor GPR54 by kisspeptins during normal puberty promotes the central release of gonadotropinreleasing hormone $(\mathrm{GnRH})$ that, in turn, leads to reproductive maturation. In humans and mice, a loss of function mutations of GPR54 prevents the onset of puberty and leads to hypogonadotropic hypogonadism and infertility. Using electrophysiological, morphological, molecular, and retrograde-labeling techniques in brain slices prepared from vGluT2-GFP and GnRH-GFP mice, we demonstrate the existence of two physiologically distinct subpopulations of GnRH neurons. The first subpopulation is comprised of septal GnRH neurons that colocalize vesicular glutamate transporter 2 and green fluorescent protein and is insensitive to metabotropic glutamate receptor agonists, but is exquisitely sensitive to kisspeptin which closes potassium channels to dramatically initiate a long-lasting activation in neurons from prepubertal and postpubertal mice of both sexes. A second subpopulation is insensitive to kisspeptin but is uniquely activated by group I metabotropic glutamate receptor agonists. These two physiologically distinct classes of GnRH cells may subserve different functions in the central control of reproduction and fertility.
\end{abstract}

Key words: GPR54; LH; FSH; brain slice; gonadotropins; hypogonadism

\section{Introduction}

A major revolution in the field of neuroendocrinology has been the discovery that loss-of-function mutations of the gene encoding the G-protein-coupled receptor GPR54 are associated with autosomal recessive idiopathic hypogonadotropic hypogonadism in humans (de Roux et al., 2003; Seminara et al., 2003; Semple et al., 2005). GPR54 knock-out mice, that have a strikingly similar phenotype as the mutation-harboring human, fail to make pulsatile luteinizing hormone and follicle stimulating hormone secretions and undergo puberty (Funes et al., 2003; Seminara et al., 2003). Kisspeptins, which include the endogenous ligand, metastin, are the natural ligands of GPR54 and are encoded by the metastasis suppressor gene KiSS-1 (Kotani et al., 2001; Muir et al., 2001; Ohtaki et al., 2001). They were originally identified as metastasis suppressor peptides that significantly suppressed metastasis of human malignant melanoma and breast carcinoma cells (Lee et al., 1996; Lee and Welch, 1997).

Within the rodent brain, in situ hybridization studies have

Received July 23, 2007; revised July 1, 2008; accepted July 2, 2008.

This work was supported by National Institutes of Health Grants MH61465 (M.A.), NS41454, and NS48476 and the State of Connecticut Department of Mental Health and Addiction Services. We thank Dr. George Aghajanian for his help with morphological studies and John Davis for assistance with single-cell RT-PCR studies.

Correspondence should be addressed to Meenakshi Alreja, Department of Psychiatry, CMHC 335A, Yale University School of Medicine, 34 Park Street, New Haven, CT 06508. E-mail: Meenakshi.Alreja@yale.edu.

DOI:10.1523/JNEUROSCI.1225-08.2008

Copyright $\odot 2008$ Society for Neuroscience $\quad$ 0270-6474/08/288003-11\$15.00/0 demonstrated the existence of KiSS-1 mRNA and peptide in several regions of the hypothalamus, with particular concentrations in the arcuate nucleus and the sexually dimorphic anteroventral paraventricular nucleus (Gottsch et al., 2004; Brailoiu et al., 2005; Kinoshita et al., 2005; Smith et al., 2005; Franceschini et al., 2006). Since the discovery of the role of GPR54 in reproduction, kisspeptins have been shown to elicit gonadotropin secretion through stimulation of gonadotropin-releasing hormone (GnRH) release (Thompson et al., 2004), presumably through direct activation of preoptic GnRH neurons (Han et al., 2005). During pubertal development, an enhanced expression of KiSS-1 and GPR54 genes, as well as increased GPR54 signaling, is detected in the hypothalamus. Most significantly, administration of kisspeptin is sufficient to induce precocious activation of the gonadotropic axis in immature rodents and monkeys (Plant et al., 2006). Thus, the kisspeptins have emerged as major gatekeepers of the hypothalamic-pituitary-gonadal axis and the kisspeptin/ GPR54 system is considered critical to normal reproductive development (Popa et al., 2005). Hypothalamic kisspeptin may also function as an essential integrator for peripheral inputs, including gonadal steroids and nutritional signals, controlling $\mathrm{GnRH}$ and gonadotropin secretion (Tena-Sempere, 2006).

Whereas kisspeptin-containing neurons are found primarily in the hypothalamic area, kisspeptin-immunoreactive fibers can be found in various regions of the brain including the medial septum/diagonal band of Broca (MSDB) (Brailoiu et al., 2005), 
and close appositions between kisspeptin fibers and GnRH neurons have been reported (Clarkson and Herbison, 2006). The MSDB is best known for its role in learning and memory that is subserved via its cholinergic and GABAergic projections to the hippocampus; it also contains the recently discovered glutamatergic neurons, function(s) of which remain to be elucidated. Impressed by the rather prominent innervation of this nucleus by kisspeptin fibers, we sought to determine the electrophysiological effects of the potent kisspeptin peptide (also known as metastin or KiSS-1 peptide) on identified MSDB cholinergic, GABAergic, glutamatergic, and GnRH neurons in brain slices prepared from rats or from $v G l u T 2-G F P$ or GnRH-GFP transgenic mice. We demonstrate that a subset of MSDB glutamatergic neurons that colocalizes $\mathrm{GnRH}$ is exquisitely sensitive to the excitatory effects of KiSS-1 even before puberty and may play a role in reproduction. A second subpopulation is insensitive to KiSS-1, but is strongly activated by group I metabotropic glutamate receptor (mGluR) agonists.

\section{Materials and Methods}

vGluT2-GFP and GnRH-GFP transgenic mice. Vesicular glutamate transporter 2 (vGluT2)-containing neurons were recorded from transgenic Swiss albino mice in which the vGluT2 promoter $1.8 \mathrm{~kb}$ upstream from the vGluT2 sequence was used to drive green fluorescent protein (GFP) expression (Huang et al., 2006; Fu and van den Pol, 2008). In a previous study, 30 of 30 GFP-expressing neurons from the hypothalamic ventromedial nucleus also expressed vGluT2 mRNA, and 17 cells showing no GFP showed no vGluT2 mRNA (Fu and van den Pol, 2008). The Swiss albino outbred strain was chosen as a background strain because of their large size; they begin to show signs of puberty at $\sim 30 \mathrm{~d}$ of age. In the present study, $v$ GluT2-GFP mice that are $30 \mathrm{~d}$ and older were considered potentially postpubertal as a conservative estimate, so as not to suggest that older mice are still prepubertal. In these mice, GFP-expressing neurons were found only in selected regions of the brain that have previously been shown to express vGluT2, including the MSDB (Fremeau et al., 2001). Further confirmation of the colocalization of GFP in vGluT2 expressing neurons is described below. GnRH-GFP neurons were recorded from $G n R H-G F P$ mice that were kindly provided by Dr. Allan E. Herbison (University of Otago, Dunedin, New Zealand); these mice have been well characterized (Han et al., 2004; Todman et al., 2005; Cottrell et al., 2006).

Labeling of septohippocampal cholinergic neurons using Cy3-192IgG. Septohippocampal cholinergic neurons were identified in rat brain slices in the living state using the fluorescent marker cyanine 3 (Cy3)-192IgG as described previously (Alreja et al., 2000; Wu et al., 2000). This technique exploits the fact that septohippocampal cholinergic neurons, but not the GABAergic neurons of the MSDB, exclusively express the low-affinity nerve growth factor receptor p75. Thus, Cy3-192IgG, which is a conjugate of the fluorochrome $\mathrm{Cy} 3$ and an antibody against the p75 receptor (192IgG), is taken up only by cholinergic terminals and thus selectively labels only the cholinergic subpopulation. The specificity of this marker and its inert nature has been thoroughly confirmed by us (Alreja et al., 2000; Wu et al., 2000, 2003, 2004a,b; Xu et al., 2004) and by others in a previous study (Härtig et al., 1998).

In anesthetized rats, Cy3-192IgG (3-5 $\mu \mathrm{l} ; 0.4 \mathrm{mg} / \mathrm{ml})$ was stereotaxically injected bilaterally into the lateral ventricle of each rat with a Hamilton syringe (22-gauge needle) at a rate of $0.5 \mu \mathrm{l} / \mathrm{min}$. The coordinates used were $0.8 \mathrm{~mm}$ posterior from bregma, $1.2 \mathrm{~mm}$ lateral from midline, and $3-4 \mathrm{~mm}$ below the dura. Two to five days later, slices were prepared from Cy3-192IgG-injected rats and used for electrophysiological recordings.

Slice preparation for electrophysiological recordings. Brain slices containing the MSDB were prepared from male Sprague Dawley albino rats (13-35 d old), male and female $v$ GluT2-GFP mice (13-54 d old) or from male and female GnRH-GFP mice (15-44 d old) (Campbell et al., 2005) using methods detailed previously (Alreja and Liu, 1996). Briefly, animals were anesthetized with chloral hydrate $(400 \mathrm{mg} / \mathrm{kg}$, i.p.) and killed by decapitation. The artificial CSF (ACSF), pH 7.35-7.38, equilibrated with $95 \% \mathrm{O}_{2}-5 \% \mathrm{CO}_{2}$, contained (in $\mathrm{mM}$ ) $126 \mathrm{NaCl}, 3 \mathrm{KCl}, 1.25$ $\mathrm{NaH}_{2} \mathrm{PO}_{4}, 10$ D-glucose, $25 \mathrm{NaHCO}_{3}, 2 \mathrm{CaCl}_{2}$, and $2 \mathrm{MgSO}_{4}$. After decapitation, brains were removed and placed in a Petri dish containing ACSF and trimmed to yield a small block containing the MSDB. Coronal slices of $300 \mu \mathrm{m}$ thickness were obtained with a Vibratome 1500 (Vibratome) and transferred to a Plexiglas recording chamber ( $1.5 \mathrm{ml}$ volume) on the fixed stage of an Olympus BX50WI scope for visualized whole-cell recording. The slices were maintained at $33 \pm 0.5^{\circ} \mathrm{C}$. One to two hours later, the slices were used for recording. The chamber was continuously perfused with normal ACSF at a rate of $2-3 \mathrm{ml} / \mathrm{min}$ and its temperature maintained at $33 \pm 0.5^{\circ} \mathrm{C}$.

Fluorescence and infrared imaging. Infrared, differential interference contrast imaging (IR-DIC) in combination with fluorescence imaging, was performed to identify and visualize neurons for patch-clamp recording with an Olympus Optical BX-50 microscope using methods described previously. vGluT2-GFP, GnRH-GFP, and Cy3-192IgG-labeled neurons were visualized using the appropriate fluorescence filter. A neuron viewed with infrared optics was considered to be the same as that viewed with fluorescence optics when the infrared image and the fluorescent image of the neuron had the same position and orientation with the IR-DIC and fluorescence.

Whole-cell recordings from MSDB neurons. The image of the cells in the slice was displayed on a video monitor, and glass pipettes used for electrophysiological recordings were visually advanced through the slice to the surface of the cell from which recordings were made. Whole-cell patch-clamp recordings were performed using previously described methods (Alreja and Liu, 1996). In brief, low-resistance (2.5-3.5 M $\Omega$ ) patch pipettes were filled with a solution containing (in $\mathrm{mM}$ ) 125 K-gluconate, 10 HEPES, 5 BAPTA $\mathrm{K}_{4}, 2.38 \mathrm{CaCl}_{2}, 4 \mathrm{Mg}$-ATP, $10 \mathrm{Na}$ phosphocreatine, and $0.3 \mathrm{Na}_{2}-\mathrm{GTP}, \mathrm{pH} 7.32-7.35$. The concentration of free $\mathrm{Ca}^{2+}$ in this solution was $97 \mathrm{nM}$, assuming an absolute affinity constant for BAPTA of $9.35 \times 10^{6} \mathrm{M}^{-1}$ (Tsien, 1980).

Data was acquired using an Axoclamp-2B and pClamp 9 (Molecular Devices). In current-clamp recordings, the output signal was filtered at $10 \mathrm{kHz}$ and spike data were acquired at a sampling frequency of $20 \mathrm{kHz}$. Access resistance was between 6 and $10 \mathrm{M} \Omega$; no compensation was done. All recordings were done with respect to an $\mathrm{Ag} / \mathrm{AgCl}$ electrode located near the outflow of the chamber. The current and voltage signals were amplified and displayed on storage oscilloscopes and also continuously recorded on a chart recorder (DASH-8xe; Astro-Med). Recordings were made from MSDB $v G l u T 2-G F P$ neurons, GnRH-GFP neurons, and septohippocampal cholinergic and GABA-type neurons. As in previous studies, septohippocampal GABA-type neurons were identified by their electrophysiological and neuropharmacological profile that included the presence of depolarizing sag and an excitatory response to muscarine (Morris et al., 1999; Alreja et al., 2000; Wu et al., 2000, 2002; Xu et al., 2004).

Intracellular labeling and morphological studies. Neurobiotin (Vector Laboratories) was added to the patch pipette solution at a concentration of $0.2 \%$. After completion of the recording session slices were fixed with a $4 \%$ paraformaldehyde and $0.4 \%$ glutaraldehyde solution overnight. After three $15 \mathrm{~min}$ rinses with $0.01 \mathrm{M}$ PBS, slices were incubated for $3 \mathrm{~h}$ with a solution containing 1:500 streptavidin conjugated with Alexa 594 (Invitrogen) in $10 \mathrm{ml}$ of $0.01 \mathrm{M}$ PBS, pH 7.4, and $50 \mu \mathrm{l}$ of $0.5 \%$ Triton $\mathrm{X}-100$ to promote penetration of streptavidin. After three $15 \mathrm{~min}$ rinses with $0.01 \mathrm{~m}$ PBS, slices were mounted with Vestashield and observed with a two-photon microscope.

Retrograde labeling with Evans blue. For systemic retrograde labeling studies, Evans blue ( $2 \%$ in sterile saline, $75 \mu$ l total volume) was injected intravenously and 3-4 d later mice were given an overdose of anesthetic and perfused transcardially with $4 \%$ paraformaldehyde. Sections were cut through the MSDB, and neurons that retrogradely transported the dye identified.

GnRH immunohistochemistry in vGluT2-GFP neurons. Mice were deeply anesthetized with ketamine/xylazine and perfused transcardially with physiological saline followed by $4 \%$ paraformaldehyde. Sections (10-30 $\mu \mathrm{m}$ thick) were cut on a cryostat. After treating with $1 \%$ normal goat serum in $0.3 \%$ Triton $\mathrm{X}-100$, sections were incubated in rabbit 
a
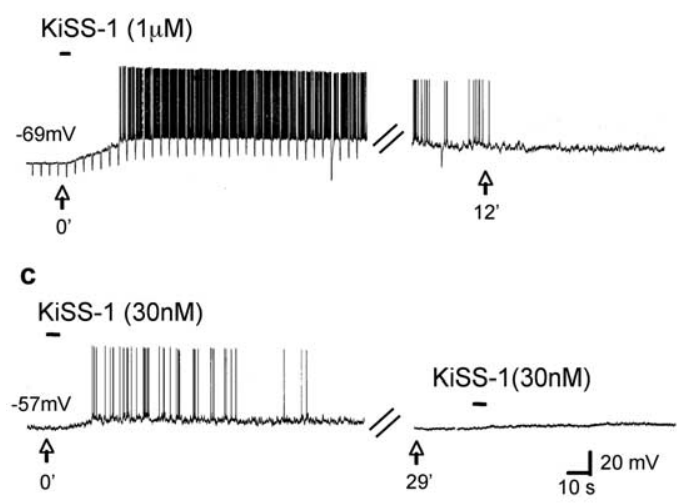

d

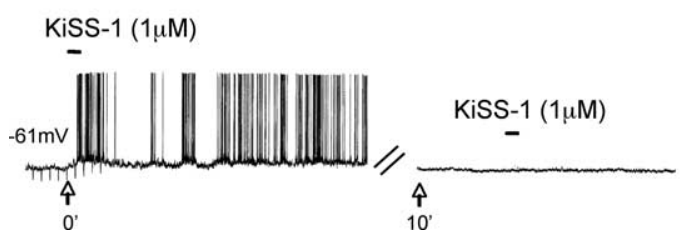

Figure 1. KiSS-1 dramatically activates a subpopulation of vGluT2-GFP neurons in the MSDB. $\boldsymbol{a}$, Whole-cell current-clamp recording shows the effect of rapid application of KiSS-1 peptide (1 $\mu \mathrm{m}, 3 \mathrm{~s})$. Note that in this quiescent neuron, which had a resting membrane potential of $-69 \mathrm{mV}$, KiSS-1 produced a $14 \mathrm{mV}$ depolarization that led to spike activity and a $58 \%$ increase in apparent input resistance. The response to KiSS-1 was prolonged and only partially reversed at 12 min. $\boldsymbol{b}$, vGluT2-GFP neurons in septal slices. $\boldsymbol{c}, \boldsymbol{d}$, Effect of $30 \mathrm{~nm}$ and $1 \mu \mathrm{m}$ KISS-1 in two neurons. Note that the second application of agonist applied $10-29 \mathrm{~min}$ later failed to yield a significant response, suggesting desensitization with both the low and high concentrations of agonist. $\boldsymbol{e}$, Bar charts demonstrate the concentration dependence of the KiSS-1 response as compiled from responses obtained in different cells. Note that the low concentration of $1 \mathrm{~nm}$ KiSS-1 yielded a $2.3 \pm 0.3 \mathrm{mV}$ depolarization, whereas a near-maximal response of a $10.5 \pm 0.7 \mathrm{mV}$ was obtained with $1 \mu \mathrm{m}$ KiSS-1, and half-maximal excitation was obtained with $10 \mathrm{~nm}$ KiSS-1. Error bars indicate SEM.

anti-GnRH antiserum (Millipore) at a dilution of 1:1500 overnight. After washing, sections were then treated with secondary goat anti-rabbit antiserum conjugated to the red fluorescent dye Alexa 594 (Invitrogen) at a dilution of 1:300 for $2 \mathrm{~h}$. After subsequent washing, sections were mounted and studied with a fluorescent microscope. The only cells labeled were those consistent with the known localization of GnRH neurons in the mouse brain (Spergel et al., 1999; Suter et al., 2000).

Single-cell RT-PCR. The single-cell reverse-transcription (RT)-PCR method used is similar to that reported previously (Kang et al., 2004) with minor modification. Briefly, the cell contents from each neuron were aspirated into a sterile glass micropipette prefilled with 5-6 $\mu$ l of DEPC-treated water. This solution was then expelled into a PCR microtube where cDNA synthesis was performed using the SuperScript III Reverse Transcriptase kit (Invitrogen) according to the manufacturer's instructions. First, an $8 \mu \mathrm{l}$ solution containing $1 \mu \mathrm{l}$ of each gene-specific oligo $(2 \mu \mathrm{M})$ and $1 \mu$ l of deoxynucleotide triphosphate $\operatorname{mix}(250 \mathrm{~mm})$ in DEPC-treated water were added to each microtube and incubated at $65^{\circ} \mathrm{C}$ for $5 \mathrm{~min}$, then cooled on ice for $1 \mathrm{~min}$. The gene-specific oligos used were the initial-round reverse primers described in the PCR procedure below. Next, $4 \mu$ l of $5 \times$ first-strand buffer, $1 \mu$ l of $0.1 \mathrm{M}$ DTT solution, $1 \mu \mathrm{l}$ of SuperScript III RT (200 U/ $\mu \mathrm{l})$, and $1 \mu \mathrm{l}$ of RNaseOUT $(40 \mathrm{U} / \mu \mathrm{l})$ were added to each microtube and incubated at $53^{\circ} \mathrm{C}$ for 60 min followed by a heat inactivation step at $70^{\circ} \mathrm{C}$ for $15 \mathrm{~min}$. Finally, $1 \mu \mathrm{l}$ of RNase $\mathrm{H}(2 \mathrm{U} / \mu \mathrm{l})$ was added to each microtube and incubated at $37^{\circ} \mathrm{C}$ for $20 \mathrm{~min}$ with the final single-cell cDNA products being stored at $-20^{\circ} \mathrm{C}$ until use.

All PCRs were performed using an iCycler thermocycler (Biorad) and the Expand High Fidelity PCR kit (Roche Diagnostics). Each PCR used only part $(5 \mu \mathrm{l}$ ) of the single-cell cDNA product for template and one pair of gene-specific primers $(30 \mathrm{pmol})$ in a total volume of $50 \mu \mathrm{l}$ and was thermocycled 35 times with an extension time of 45 s. Amplified products were run on $1.5 \%$ agarose gels and visualized using ethidium bro-
MSDB vGluT2-GFP
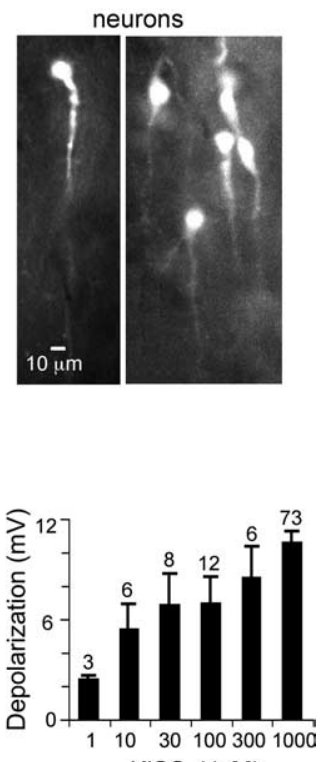

KiSS-1(nM) mide. Gene-specific primer pairs were designed to amplify mouse $\beta$-actin, vGluT2, and GnRH cDNA sequences based on GenBank accession numbers NM_007393, NM_080853, and NM_008145 respectively, using Oligo Primer Analysis Software version 6.89 (Molecular Biology Insights). A minimum of $550 \mathrm{bp}$ of intronic sequence was spanned in the design of each amplicon to easily distinguish cDNA amplification products from any that might arise from the amplification of genomic DNA. Because expression was low, detection of vGluT2 required a second round of PCR (nested); 35 cycles were used in this second round. A diluted equivalent of $0.25 \mu \mathrm{l}$ of initial amplification product was used as template in the nested reaction. Digital photographs of the blots were made, and the contrast and brightness of the entire blot were corrected as a unit with Adobe Photoshop. The following list details the target gene, annealing temperature, amplicon length and primer sequences for each PCR: $\beta$-actin, $56.7^{\circ} \mathrm{C}, 523 \mathrm{bp}$, F 5'-GCCAACCGTGAAAAGATGAC-3', R 5' CAACGTCACACTTCATGATG-3'; vGluT2 (initial), $53.8^{\circ} \mathrm{C}, 388 \mathrm{bp}, \mathrm{F} 5^{\prime}$-CATTTCAGATGGCGTTGGCAC-3', R 5'-CTTATAGGTGTACGCGTCTTG-3'; vGluT2 (nested), $53.6^{\circ} \mathrm{C}, 279$ bp, F 5'-CTATCATTGTTGGTGCAATGAC-3', $\mathrm{R} \quad 5^{\prime}$-AGCCTCCATTCTCCTGTGAG-3'; GnRH, $58.9^{\circ} \mathrm{C}, 230 \mathrm{bp}, \mathrm{F}$ 5'-CGGCATTCTACTGCTGACTGTGTG-3', R 5'-GCCTGGCTTCCTCTTCAATCAGAC-3'.

Drugs and drug application. KiSS-1 (metastin 45-54 amide, kisspeptin-10) and $\mathrm{BaCl}_{2}$ were obtained from Sigma. 3,4-Dihydroxyphenylglycol (DHPG) and muscarine were obtained from Tocris Bioscience. TTX was obtained from Alomone Labs. All drugs were diluted in ACSF from previously prepared stock solutions that were prepared in water and stored at $-20^{\circ} \mathrm{C}$. Agonists were applied using a Y-tube (Wu et al., 2003). Ion channel blockers were bath applied.

\section{Results}

\section{KiSS-1 selectively activates a subpopulation of $v G l u T 2-G F P$} neurons in the MSDB

During whole-cell current-clamp recordings from a subpopulation of MSDB $v$ GluT2-GFP neurons in mouse brain slices we observed dramatic excitatory effects after very brief applications of the KiSS- 1 peptide ( $0.1 \mathrm{~nm}$ to $1 \mu \mathrm{M}, 5-15 \mathrm{~s}$ ). Sixty percent of the KiSS-1-sensitive $v$ GluT2-GFP neurons fired spontaneously and the remaining had a mean resting membrane potential (RMP) of $-61.2 \pm 2.3 \mathrm{mV}(n=187)$ with a maximum negative value of $-73 \mathrm{mV}$. These neurons responded to KiSS-1 with a membrane depolarization and a significant increase in basal firing rates (control firing rate, $1.3 \pm 0.2 \mathrm{~Hz}$; KiSS-1, $8.9 \pm 0.6 \mathrm{~Hz} ; n=44$; $p<0.0001$, Student's paired $t$ test) (Fig. $1 a, c, d$ ). The KiSS-1induced activation of $v$ GluT2-GFP neurons was very prolonged; a $5 \mathrm{~s}$ application of $1 \mu \mathrm{M}$ KiSS-1 yielded responses that lasted an average of $16 \pm 1.5 \mathrm{~min}$ (range, 3-60 min; median, $12.5 \mathrm{~min} ; n=$ 62). Interestingly, in six neurons with a mean RMP of $-61.2 \pm$ $1.6 \mathrm{mV}$, a second application of KiSS-1 applied at an interval ranging from 10 to 48 min yielded little/no second response both with low and high concentrations of the agonist (first application, $7.2 \pm 1.6 \mathrm{mV}$; second application, $0.7 \pm 0.4 \mathrm{mV} ; p<0.005$ ) (Fig. $1 c, d)$. This apparent desensitization of the KiSS-1 response therefore, precluded repeated applications of KiSS-1 to the same neuron. 
To examine the concentration dependency of the KiSS-1 response, we, therefore compared the magnitude of KiSS-1 induced activation in different $v$ GluT2-GFP neurons using six different concentrations of agonist ranging from $1 \mathrm{nM}$ to $1 \mu \mathrm{M}$. Fifty-seven percent of these neurons fired spontaneously, the remaining quiescent neurons had mean resting membrane potentials of $-65 \pm$ $0.72 \mathrm{mV}$. As illustrated in Figure 1e, the lowest concentration of 1 nM KiSS-1 produced a $2.3 \pm 0.3 \mathrm{mV}$ depolarization, whereas a near-maximal depolarizing response of $10.5 \pm 0.72 \mathrm{mV}(n=73)$ was obtained with $1 \mu \mathrm{M}$ KiSS-1; half-maximal responses were obtained with $10 \mathrm{~nm}$ KiSS-1.

As mentioned above, only a subpopulation of MSDB $v$ GluT2GFP neurons responded to KiSS-1; this subpopulation was unique in that it did not respond to the group 1 metabotropic glutamate receptor agonist DHPG with activation either before or after KiSS-1 application (Fig. 2a2,e). In contrast, vGluT2-GFP neurons that exhibited an excitatory response to DHPG did not respond to even prolonged applications of KiSS-1, regardless of whether KiSS-1 was administered before or after DHPG (Fig. $2 b 2, e)$. Similarly, septohippocampal cholinergic and GABAergic neurons located within the same nucleus also failed to respond to KiSS-1 (Fig. 2c1-e); these subpopulations are also strongly activated by DHPG (Wu et al., 2003, 2004a).

Electrophysiologically, KiSS-1-activated vGluT2-GFP neurons could be differentiated from other MSDB neurons as they lacked significant classical inward-rectification as well as timedependent rectification in response to hyperpolarizing pulses. In the initial, random sampling, the KiSS-1 sensitive subpopulation comprised of $25 \%$ of the $v$ GluT2-GFP neurons; however, after identification of unique morphological features of this subpopulation (see below), it became possible to identify these neurons visually in the slice before recording. Thus, KiSS-1 has a profound excitatory effect on a unique subpopulation of neurons within the MSDB that can be readily identified by the lack of an excitatory response to the group 1 metabotropic glutamate receptor agonist, DHPG (Fig. 2e). The remaining data describe the effects of KiSS-1 in this DHPG-insensitive subpopulation of MSDB $v$ GluT2-GFP neurons.

The excitatory effects of this puberty-promoting peptide KiSS-1 was statistically similar in neurons recorded from brain slices prepared from male $(8.79 \pm 0.5 \mathrm{mV} ; n=118)$ or female $(8.86 \pm 0.5 \mathrm{mV} ; n=72)$ mice ranging from postnatal day (P11)$\mathrm{P} 54$. Additionally, there was no significant correlation between the age of the animals and the amplitude of KiSS-1 response in either sex (Pearson's coefficient, -0.22 ; male, $n=118$; Pearson's coefficient, -0.06 ; female, $n=72$ ). The resting membrane potentials for the above cells are as follows: of the 118 cells from male mice, 58 were quiescent and had a RMP of $-62.3 \pm 0.6 \mathrm{mV}$ and the remaining 60 cells fired at rest; similarly, 34 of 72 cells from female mice were quiescent with RMP of $-61.8 \pm 0.8 \mathrm{mV}$ and the remaining 38 cells fired at rest. The $v G l u T 2-G F P$ mice used in the current study become reproductively active at $\sim \mathrm{P} 30$ (see Materials and Methods). The number of neurons that responded to low nanomolar concentrations of KiSS-1 was similar in brain slices prepared from 11 - to 30-d-old mice or from 31- to 54 -d-old mice. Thus, whereas $67 \%$ and $63 \%$ of neurons responded to $1 \mathrm{~nm}$ KiSS-1 in both the groups, $100 \%$ of neurons responded to $100 \mathrm{~nm}$ KiSS-1 in the two groups (Fig. $3 b$ ). Similarly, there was no statistically significant difference in the magnitude of excitation in the two groups of mice with either $1 \mathrm{nM}$ KiSS-1 (P11-P30, $2.3 \pm 0.3 \mathrm{mV}, n=3$; P31-P54, $3.5 \pm 1.5 \mathrm{mV}$, $n=4)$ or $10 \mathrm{~nm} \mathrm{KiSS}-1$ (P11-P30, $5.3 \pm 1.6 \mathrm{mV}, n=6$; P31-P54, $5.0 \pm 1.1 \mathrm{mV}, n=3$ ) (Fig. $3 c$ ).
KiSS-1 activated vGluT2-GFP neuron

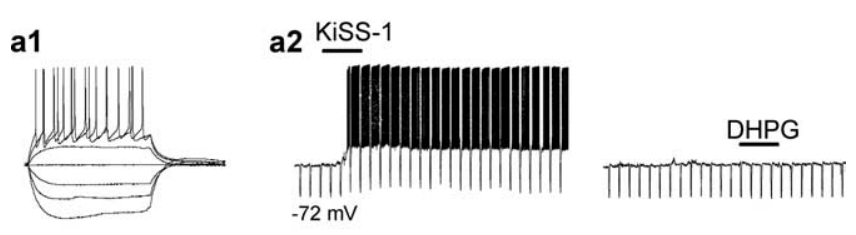

KiSS-1 insensitive vGluT2-GFP neuron b1

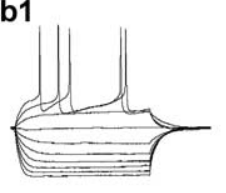

b2

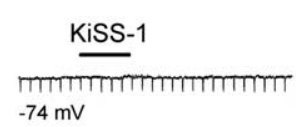

Septohippocampal cholinergic neuron

c1

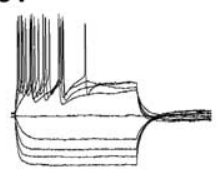

c2

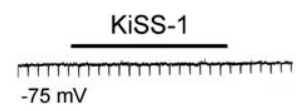

Septohippocampal GABA-type neuron

d1

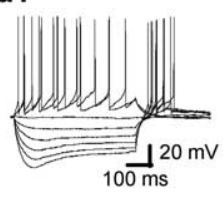

d2

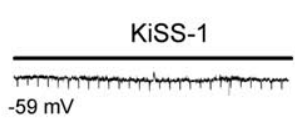

e

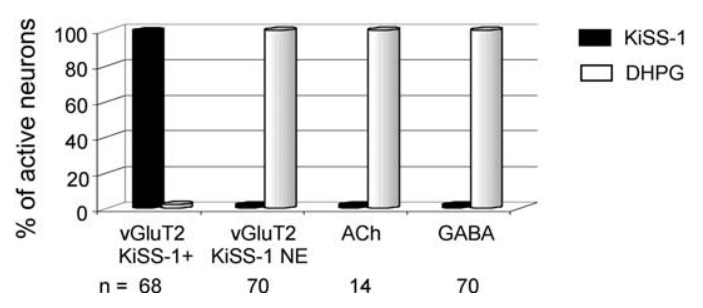

Figure 2. KiSS-1 selectively activates a subpopulation of vGluT2-GFP neurons within the MSDB. a1, a2, Electrophysiological signature of a vGluT2-GFP cell and its excitatory response to a rapid application of KiSS-1 (15s, $1 \mu \mathrm{M})$. Note that the group I metabotropic glutamate receptor agonist DHPG did not activate the cell. $\boldsymbol{b} \mathbf{1}, \boldsymbol{b} \mathbf{2}$, In contrast to $\boldsymbol{a} \mathbf{1}$ and $\boldsymbol{a} \mathbf{2}$, the remaining vGluT2-GFP neurons responded to DHPG but not to KiSS-1 with an activation. $\mathbf{c} \mathbf{1 - d 2}$, Examples of septohippocampal cholinergic and GABA-type neurons within the MSDB. Again, note the lack of response to even prolonged applications of $1 \mu \mathrm{m} \mathrm{KiSS}-1$ ( 30 s to $2 \mathrm{~min}$ ) but a strong excitatory response to DHPG. $\boldsymbol{e}$, Bar chart summarizes the data and shows that although all 68 KiSS-1excited neurons were insensitive to DHPG, the remaining neurons of the MSDB were sensitive to DHPG but not to KiSS-1. Thus, a subpopulation of DHPG-insensitive MSDB vGluT2-GFP responds to KiSS-1 with a dramatic excitation.

The KiSS-1-induced depolarization is mediated via a direct postsynaptic mechanism that involves a closing of $\mathrm{Ba}^{2+}$ sensitive $\mathrm{K}^{+}$channels

Because the strongly desensitizing properties of KiSS-1 preclude repeated applications of agonist to the same slice, we identified putative KiSS-1-sensitive cells by their lack of response to DHPG. As mentioned above, $100 \%$ of DHPG-insensitive vGluT2-GFP neurons respond to KiSS-1 with activation under normal resting 
a1

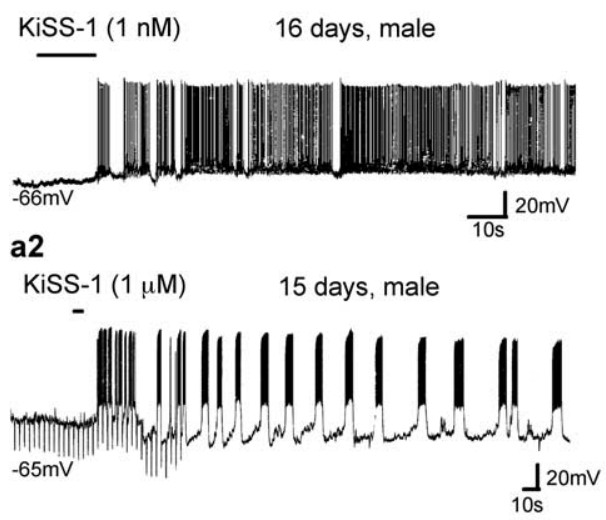

a3

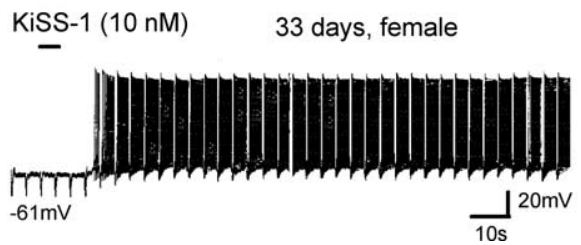

Figure 3. KiSS-1 activates MSDB vGluT2-GFP neurons in prepubertal and postpubertal male and female mice. $\boldsymbol{a} 1-\boldsymbol{a} 3$, Currentclamp recordings show excitatory effects of $1 \mathrm{~nm}$ to $1 \mu \mathrm{m}$ KiSS-1 in male and female mice of different ages. VGluT2-GFP mice used in this study become reproductively active at postnatal day 30 . Note the bursting activity in $\mathbf{a 2}$. KiSS-1-activated vGluT2-GFP neurons often displayed bursting activity both in the absence and presence of KiSS-1. $\boldsymbol{b}$, Bar chart shows that the number of cells that responded to different concentrations of KiSS-1 in prepubertal versus pubertal mice did not vary significantly, albeit in both groups, $\sim 65 \%$ of neurons responded to $1 \mathrm{~nm}$ KiSS- 1 with an excitation, whereas $100 \%$ of neurons responded to $100 \mathrm{~nm}$ KiSS-1.c, Depolarization in millivolts in response to 1 and $10 \mathrm{~nm}$ KiSS-1 in the prepubertal versus postpubertal mice. Note the insignificant difference (n.s.). Error bars indicate SEM.

conditions. DHPG-insensitive MSDB $v$ GluT2-GFP neurons were identified and KiSS-1 was applied in the presence of TTX or $\mathrm{Ba}^{2+}$-containing ACSF, or in the presence of "zero" $\mathrm{Ca}^{2+} /$ high $\mathrm{Mg}^{2+}$ ACSF. As shown in Figure 4, the KiSS-1 response in DHPG-insensitive MSDB vGluT2-GFP neurons was present both in zero $\mathrm{Ca}^{2+} /$ high $\mathrm{Mg}^{2+}$ ACSF and in TTX-containing ACSF (Fig. $4 a, b, f$ ), suggesting involvement of a direct postsynaptic mechanism (control, $10.6 \pm 0.94 \mathrm{mV}, n=73$; TTX; $11.3 \pm 2.2$ $\mathrm{mV}, n=6$; zero $\mathrm{Ca}^{2+} /$ high $\mathrm{Mg}^{2+}, 12.6 \pm 2.8 \mathrm{mV}, n=8$; Student's $t$ test, not significant). The cells in the TTX and zero $\mathrm{Ca}^{2+}$ / high $\mathrm{Mg}^{2+}$ experimental groups had resting membrane potentials of $-65 \pm 1.4 \mathrm{mV}$ and $-62.8 \pm 1.6 \mathrm{mV}$ respectively, whereas the 42 quiescent cells in the control group averaged $-65 \pm 0.8$ $\mathrm{mV}$; the remaining 31 cells were firing.

In the presence of TTX, The KiSS-1-induced membrane depolarization was accompanied by a $36.2 \pm 8.8 \%$ increase in apparent input resistance $(n=5)$, suggesting a net closing of ion channels. Next we examined the reversal potential of the KiSS-1 response in 10 cells. In six cells held close to the calculated potassium equilibrium potential $\left(E_{\mathrm{k}}\right)$ of $-102 \mathrm{mV}$, KiSS-1 produced a depolarization of only $1.0 \pm 0.5 \mathrm{mV}$ (Fig. $4 c 1$ ). In another four cells, KiSS-1 response was measured at two potentials, at the RMP and close to $E_{\mathrm{k}}$, by giving repetitive hyperpolarizing pulses. Thus, with one application of KiSS-1, we were able to confirm the presence of and measure the KiSS-1 response at rest as well as measure its magnitude at $E_{\mathrm{k}}$. Three of these four neurons had a RMP of $-69 \pm 2 \mathrm{mV}$ and the fourth cell fired spontaneously; in these cells, KiSS-1 produced a $9.3 \pm 2 \mathrm{mV}$ at rest and no response to KiSS- 1 at $E_{\mathrm{k}}$ (Fig. $4 c 2$ ).

Additionally, in 10 cells ( 4 of which fired spontaneously and the remaining 6 had a mean RMP of $-65 \pm 2.3 \mathrm{mV}$ ), similar to
KiSS-1, bath perfusion with $\mathrm{BaCl}_{2}$ by itself produced a depolarization of $11.9 \pm 2.0$ $\mathrm{mV}$ that was accompanied by a $35 \pm 8.1 \%$ increase in apparent input resistance, which resulted in cell firing in all 10 cells. KiSS-1 failed to produce a statistically significant depolarization in slices treated with external $\mathrm{BaCl}_{2}\left(\mathrm{BaCl}_{2}, 0 \pm 0 \mathrm{mV} ; n=\right.$ $10)$ in contrast to the KiSS-1 response in 10 randomly chosen control cells with mean membrane potentials similar to that before $\mathrm{Ba}^{2+}(10.5 \pm 2.4 \mathrm{mV} ; p<0001)$ or 10 firing control cells randomly selected similar to the membrane conditions after treatment with $\mathrm{Ba}^{2+}(11 \pm 2.4 \mathrm{mV} ; p<$ 0001), suggesting involvement of $\mathrm{Ba}^{2+}$ sensitive $\mathrm{K}^{+}$channels (Fig. $4 d, f$ ). The KiSS-1 response also persisted in neurons after buffering of internal $\mathrm{Ca}^{2+}$ after addition of $10 \mathrm{~mm}$ BAPTA to the regular pipette solution (KiSS-1, $14.9 \pm 2.6 \mathrm{mV} ; n=$ 6) (Fig. 4e,f).

\section{KiSS-1-activated MSDB $v$ GluT2-GFP neurons colocalize GnRH mRNA.}

Because functionally KiSS-1 is strongly implicated in reproductive maturation via the release of $\mathrm{GnRH}$, we speculated that KiSS-1-activated $v G l u T 2-G F P$ neurons could be related to the GnRH neurons that also coexist within the MSDB (Merchenthaler et al., 1989a,b; Spergel et al., 1999; Suter et al., 2000). We therefore, asked the question: could vGluT2 MSDB neurons colocalize GnRH? As such, we performed immunocytochemical studies to determine whether MSDB $v$ GluT2-GFP neurons colocalize GnRH (Fig. 5). We counted a total of 750 green cells within the MSDB of five $v G l u T 2-G F P$ mice. In the same area, we found 154 red GnRH-immunoreactive neurons. This is consistent with the view that the glutamatergic neurons in the MSDB are heterogeneous and only a subpopulation contains GnRH. Of the $154 \mathrm{GnRH}$-immunoreactive neurons, 130 expressed GFP. Based on five brains, a mean of $84+$ $2.4 \%$ (SEM) of the GnRH-immunoreactive neurons also contained GFP, a finding that is fairly consistent with a previous report that found $99 \%$ of GnRH neurons colocalized vGluT2 mRNA (Hrabovszky et al., 2004). The $84 \%$ may be an underestimate, because the paraformaldehyde fixative, permeabilizing detergent, and multiple buffer changes associated with immunostaining would all reduce the amount of detectable GFP.

To specifically determine whether KiSS-1-activated $v$ GluT2GFP neurons colocalize GnRH, we performed single-cell RTPCR analysis in KiSS-1-activated vGluT2-GFP neurons. KiSS-1activated neurons were identified using cell-attached recordings (Fig. 6a1,a2) after which the whole-cell mode was established to harvest the cytoplasm for single-cell RT-PCR (Fig. 6a3). Ten of $12 v$ GluT2-GFP neurons expressed vGluT2 mRNA. Six of these neurons were also tested for the presence of GnRH mRNA; all 6 KiSS-1-activated MSDB $v$ GluT2-GFP neurons colocalized GnRH mRNA. In contrast, control neurons $(n=6)$ from the neighboring striatal region were negative for vGluT2 and GnRH messenger mRNA (Fig. 6b). The absence of detectable vGluT2 mRNA in 2 of 12 cells could be caused by lack of vGluT2 in a subpopulation of green cells, or could be caused by the low level of vGluT2 
a 'zero' $\mathrm{Ca}^{2+} /$ high $\mathrm{Mg}^{2+}-\mathrm{ACSF}$

Kis

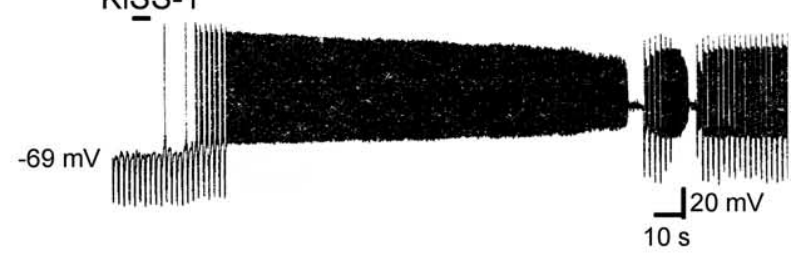

b TTX

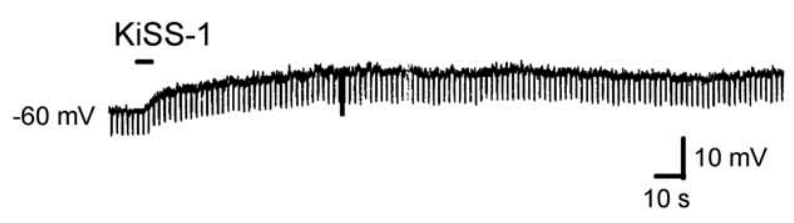

c1
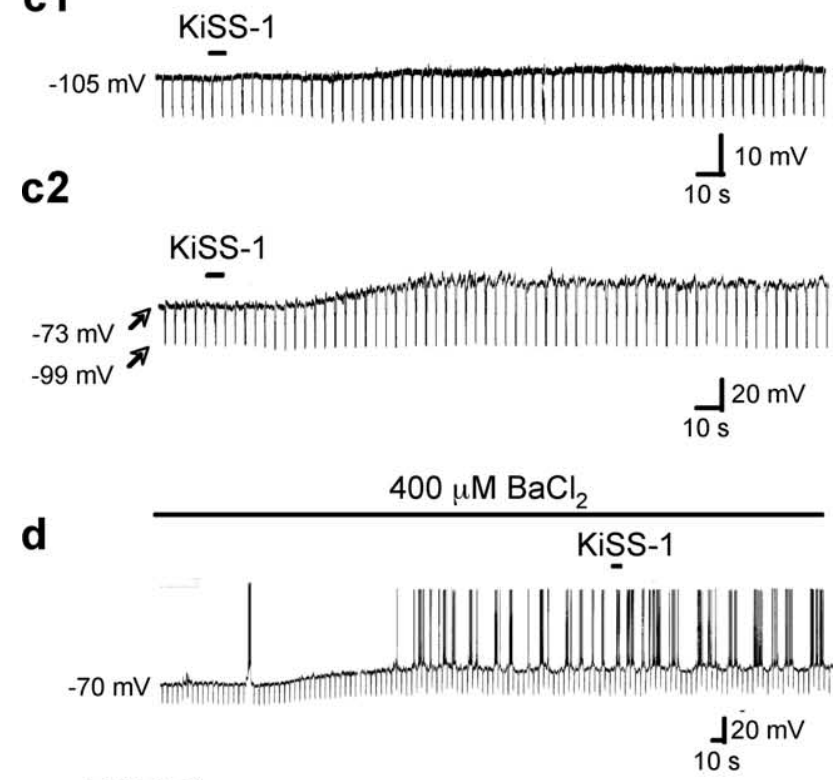

e BAPTA
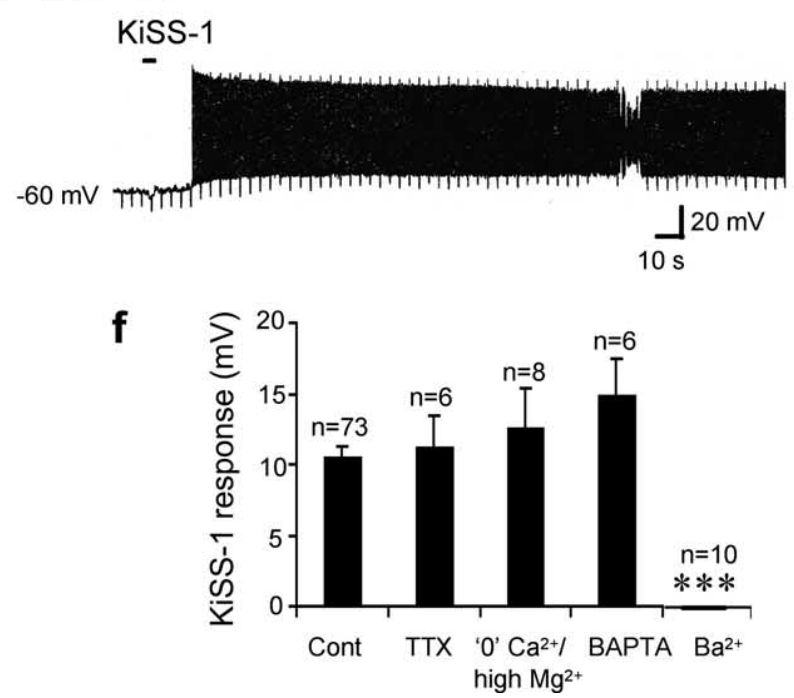

Figure 4. KiSS-1 activates vGluT2-GFP neurons via a direct postsynaptic mechanism that involves a closing of $\mathrm{K}^{+}$channels. $\boldsymbol{a}$, Current-clamp recording from a vGluT2-GFP neuron shows

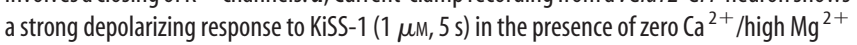
ACSF. The hyperpolarizing pulse was turned off in between to prevent distortion of the firing pattern. $\boldsymbol{b}$, At a membrane potential of $-60 \mathrm{mV}$, KiSS-1 produced a $14 \mathrm{mV}$ depolarization with
mRNA in these cells, compounded using only one quarter of a single cell product for each reaction, which may have not been sufficient to detect the signal in every cell.

\section{MSDB $v G l u T 2-G F P$ neurons access the}

peripheral vasculature

A unique characteristic of GnRH neurons is that many of their axons terminate in the median eminence, and therefore have access to the peripheral vasculature because of the weak blood brain barrier here. To determine whether MSDB vGluT2-GFP neurons also have a similar access to the peripheral vasculature, we looked for retrogradely labeled $v$ GluT2-GFP neurons within the MSDB after intravenous injection of Evans blue, a tracer that does not cross the blood-brain-barrier and, hence, is taken up only by neurons in the CNS whose axons terminate on fenestrated capillaries, such as the capillaries of the median eminence. Retrograde labeling has been used various to label GnRH cells in the MSDB (Merchenthaler et al., 1989b; Witkin, 1990; Weiss and Cobbett, 1992; Livne et al., 1993; Parducz et al., 2003). As shown in Figure $7 a$, Evans blue-labeled neurons could be readily found within the MSDB. More significantly, Evans blue colocalized in somewhat less than a fifth of $v G l u T 2-G F P$ neurons, suggesting either that a number of the total population of $v$ GluT2-GFP neurons do not access the peripheral vasculature and/or were not labeled strongly enough to detect.

\section{KiSS-1-activated MSDB $v$ GluT2-GFP neurons are morphologically similar to GnRH neurons}

GnRH neurons in the brain not only access the peripheral vasculature but are also endowed with a unique morphology. To determine whether the KiSS-1-activated neurons of the MSDB have a morphology similar to that reported for GnRH neurons, we loaded KiSS-1-activated vGluT2-GFP neurons with neurobiotin during whole-cell recording (Fig. 7c). Cell morphologies, reconstructed from images taken every $1 \mu \mathrm{m}$ using two-photon microscopy in combination with $z$-stack reconstruction, yielded morphological features suggestive of GnRH neurons. All 48 labeled neurons had a vertical orientation; 35 of 48 labeled neurons were clearly bipolar with the processes emanating from the opposite ends of the long axis of the soma with the proximal process showing significant looping (Fig. $7 d, e$ ). In addition to the above we observed that the process emanating from the ventral end of the soma extended long distances aiming for the base of the brain (Fig. 7g). In the 11 neurons that were analyzed in detail, the soma diameter along the longest axis ranged from 16 to $28 \mu \mathrm{m}$ with a mean diameter of $19 \pm 0.97 \mu \mathrm{m}$. The length of the processes, some of which were clearly cut as they exited the brain slice, ranged

\footnotetext{
$\leftarrow$

a $28 \%$ increase in apparent input resistance in the presence of $2 \mu \mathrm{m} \mathrm{TTX.} \mathrm{c1,} \mathrm{In} \mathrm{contrast,} \mathrm{when}$ the cell was held at the calculated $E_{\mathrm{k}}$ of $-101 \mathrm{mV}$, KiSS-1 produced a $1-2 \mathrm{mV}$ depolarization, suggesting a reversal potential close to $E_{\mathrm{k}}$. $\mathbf{c}$, A cell with a RMP of $-73 \mathrm{mV}$ that was pulsed every $5 \mathrm{~s}$ to $-99 \mathrm{mV}$. KiSS-1 produced a depolarization at $-73 \mathrm{mV}$ but failed to produce a depolarization at $-99 \mathrm{mV}$, suggesting a reversal potential close to the calculated $E_{\mathrm{k}}$ of -102 $\mathrm{mV}$. $\boldsymbol{d}$, Bath application of $400 \mu \mathrm{m} \mathrm{BaCl}$, a blocker of $\mathrm{K}^{+}$channels, mimicked the effect of KiSS-1 by depolarizing the cell with an associated increase in apparent input resistance. Addition of KiSS-1 in the presence of $\mathrm{BaCl}_{2}$ failed to further depolarize the neuron, suggesting occlusion. $\boldsymbol{e}$, Chart record shows that KiSS-1 depolarization persisted after buffering of internal $\mathrm{Ca}^{2+}$ using BAPTA. $f$, Bar chart summarizes the magnitude of KiSS-1 depolarization in control, TTX, and zero $\mathrm{Ca}^{2+} /$ high $\mathrm{Mg}^{2+}$ ACSF, and in presence of internal BAPTA and external $\mathrm{Ba}^{2+}$, suggesting involvement of a direct postsynaptic mechanism that does not depend on internal calcium. ${ }^{* * *} p<0.001$. Error bars indicate SEM.
} 


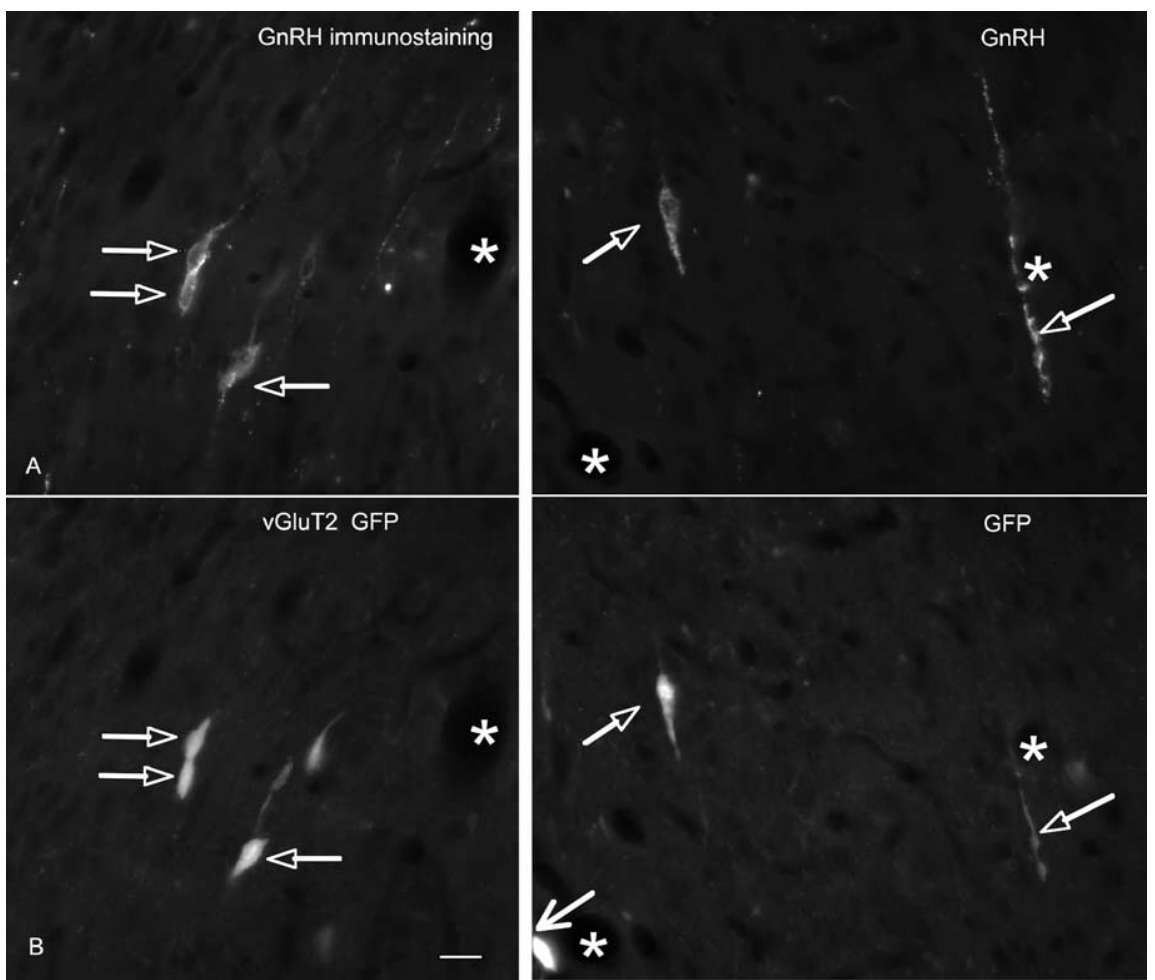

Figure 5. GnRH immunoreactivity colocalizes in vGluT2-GFP neurons. $\boldsymbol{A}, \mathrm{GnRH}$-immunoreactive perikarya and processes in the MSDB of vGluT2-GFP mice. $\boldsymbol{B}$, vGluT2-GFP-immunoreactive perikarya and processes. Note the double-labeled structures (open arrows). Also note the strongly immunoreactive vGluT2-GFP neuron in the bottom of the field (larger arrow) that was not GnRH positive. Thus, some but not all vGluT2-GFP neurons colocalize GnRH immunoreactivity. Asterisks indicate blood vessels. a1

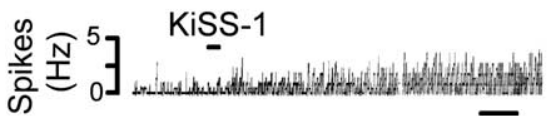

$\overline{20 \mathrm{~s}}$

a3

\section{MSDB} (vGluT2-GFP Mouse)

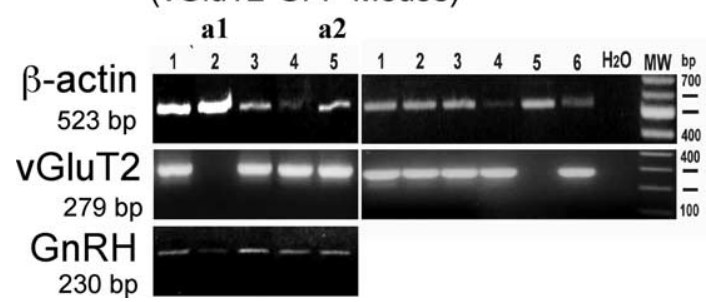

a2

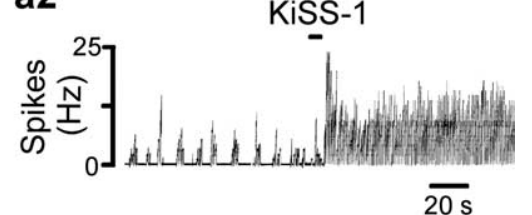

b Striatum (vGluT2-GFP Mouse)

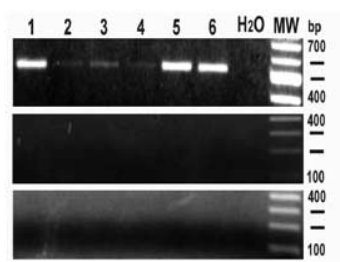

Figure 6. GnRH, vGluT2, and GPR54 mRNA colocalize in KiSS-1-activated MSDB vGluT2-GFP neurons. KiSS-1-activated vGluT2GFP MSDB neurons were identified using cell-attached recordings, after which the cell cytoplasm was harvested for single-cell RT-PCR using the whole-cell mode of patch clamping. a1, a2, Cell-attached recordings show two KiSS-1-activated vGluT2-GFP neurons from which cytoplasm was harvested for mRNA analysis. a3, A different neuron is shown in each of the 11 lanes. Cells in $\boldsymbol{a} \mathbf{1}$ and $\boldsymbol{a} 2$ are shown in lanes 2 and 5 . To demonstrate a successful harvest of a cell, $\beta$-actin was used. Note that 9 of 11 vGluT2-GFP cells shown expressed vGluT2 mRNA. GnRH mRNA expression was observed in 5 of 5 cells shown. One control lane was used with water $\left(\mathrm{H}_{2} \mathrm{O}\right)$ instead of cell contents; as expected, this lane was negative. $\boldsymbol{b}$, For control purposes, we also harvested neurons from the neighboring striatum, where no vGluT2 or GnRH is expected. All six cells expressed $\beta$-actin, but none of the cells showed GnRH or vGluT2 expression. MW, Molecular weight.

from 257 to $1696 \mu \mathrm{m}$ with a mean length of $677 \pm 138.7 \mu \mathrm{m}$ and a median length of $482 \mu \mathrm{m}$. We found no evidence of dye coupling either between the KiSS-1-activated neurons or any other neuronal subtype within the MSDB in young or old mice.
KiSS-1 activates a subpopulation of GnRH-GFP neurons that is insensitive to DHPG

Because the above-mentioned data strongly suggested that a subpopulation of MSDB vGluT2-GFP neurons colocalizes $\mathrm{GnRH}$, we tested the effect of KiSS-1 on identified MSDB GnRH neurons in brain slices from a different transgenic mouse line expressing GFP under control of the GnRH promoter. A similar response was obtained in male and female mice and no age difference was noted in the range tested (15-44 d old); as such, all data has been pooled together. Interestingly, we encountered two subtypes of GnRH neurons based on their sensitivity to the group I glutamate metabotropic receptor agonist DHPG and to KiSS-1 using both the whole-cell mode of patch clamping as well as the noninvasive cell-attached mode of recording. Of the total $64 G n R H-G F P$ neurons tested, 47 neurons were examined using the whole-cell mode and the remaining 17 were recorded using the cell-attached mode. In whole-cell recordings, of the 47 neurons recorded, 21 responded to DHPG but not to KiSS-1 with activation; the remaining 26 were activated by KiSS-1 but not by DHPG (Fig. 8a1,a2). Thus, similar to $v$ GluT2-GFP mice, during whole-cell recordings $100 \%$ of DHPG-insensitive neurons responded to KiSS-1 and $100 \%$ of DHPG-sensitive neurons failed to respond to KiSS-1. Similarly, in the cell-attached mode, 13 of 17 neurons did not respond to DHPG but all of these neurons responded to KiSS-1 with an excitation; all of the remaining 4 cells responded to DHPG but not to KiSS-1 with a strong excitation (Fig. $8 b 1, b 2)$. Thus, similar to vGluT2-GFP neurons, $100 \%$ of DHPG-insensitive GnRH-GFP neurons responded to KiSS-1 and vice versa using either the cell-attached mode or whole-cell mode of recording.

Overall, using the two modes of recording, $61 \%$ of GnRH-GFP neurons belonged to the population that responded to KiSS-1 but not to DHPG with an excitation, characteristics similar to those of the KiSS-1-activated MSDB vGluT2-GFP neurons recorded from in this study (Fig. $2 a 1, a 2)$. Thus, based on neuropharmacological properties, we were able to identify two subsets of MSDB GnRH-GFP neurons. Moreover, the KiSS-1-sensitive subpopulation of GnRH-GFP neurons is remarkably similar to the KiSS-1 sensitive GnRH-colocalizing $v$ GluT2-GFP neurons recorded from in this study.

As a next step, we performed single-cell RT-PCR studies in GnRH-GFP cells to determine whether they colocalized vGluT2 mRNA. Interestingly, 12 of $12 \mathrm{GnRH}$-GFP neurons were positive 


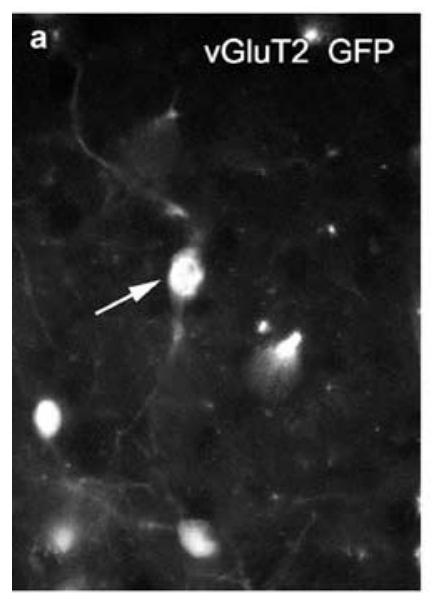

C

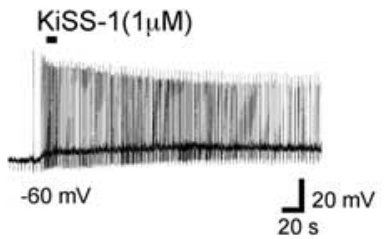

d
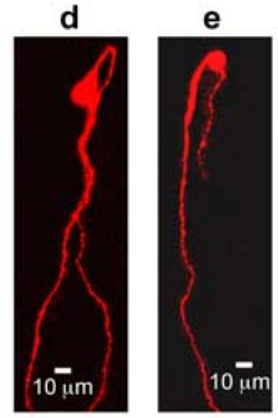

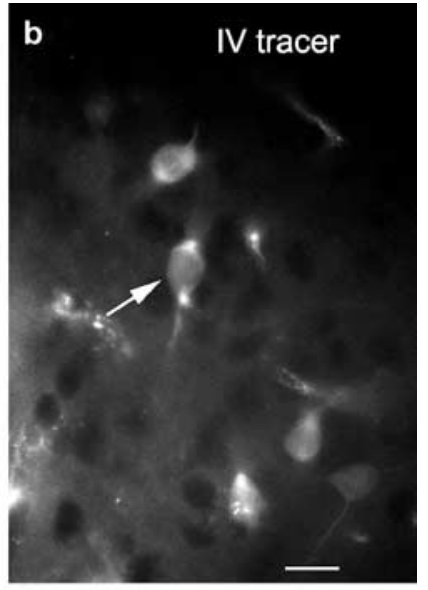

f
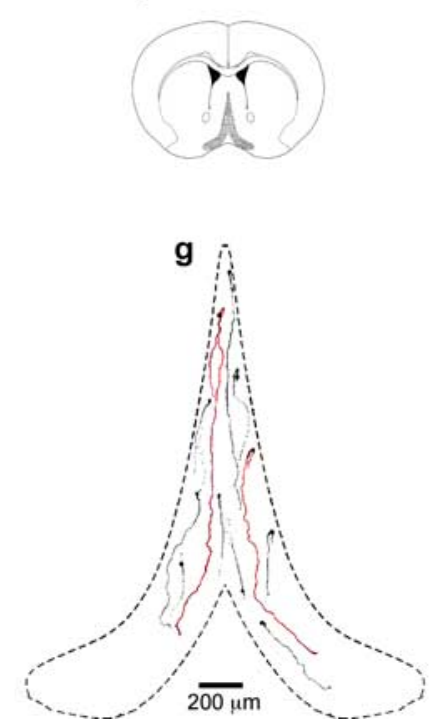

Figure 7. MSDB VGluT2-GFP neurons access the peripheral vasculature and have morphological characteristics similar to those of GnRH neurons $\boldsymbol{a}$, Three VGluT2-GFP neurons in the MSDB. $\boldsymbol{b}$, MSDB neurons that were labeled after an intravenous injection of Evans blue. Note that one of the three VGIUT2-GFP neurons also colocalized Evans blue (solid arrow), suggesting that some but not all vGluT2-GFP neurons do access the peripheral vasculature. Also note that not all Evans-blue-labeled neurons colocalized vGluT2-GFP. c, Current-clamp recording shows KiSS-1 excitation in a VGluT2-GFP neuron that was filled with neurobiotin during whole-cell recording. $\boldsymbol{d}, \boldsymbol{e}, \mathbf{Z}$-stack reconstruction of two-photon images of two neurobiotin-filled KiSS-1activated MSDB vGluT2-GFP neurons. The cell in $\boldsymbol{d}$ had a soma diameter of $28 \mu \mathrm{m}$ along the long axis and two cell processes: a looping proximal process and a distal process that measured 1696 $\mu \mathrm{m}$ long. The bipolar cell in $\boldsymbol{e}$ had a soma diameter of $17 \mu \mathrm{m}$ and a cell process that measured $1196 \mu \mathrm{m}$ long until it got cut while exiting the slice. Note the bipolar somas; neither cell exhibited somatic or dendritic spines. $\boldsymbol{f}$, Coronal section showing the MSDB (shaded region). $\boldsymbol{g}$, Location of these two neurons within the MSDB along with the location of nine other similarly filled cells. Note the elongated bipolar cell bodies and vertical orientation; the long primary dendrites tended to extend to the base of the brain. Some of the shorter processes belong to neurons whose processes were cut while exiting the brain. Scale bar: (in $\boldsymbol{b}) \boldsymbol{a}, \boldsymbol{b}, 20 \mu \mathrm{m}$.

for vGluT2 mRNA (Fig. 8c). In contrast, none of the six neighboring striatal neurons from the GnRH-GFP mouse tested positive for vGluT2 mRNA (Fig. $8 d$ ). These results are consistent with the view that GnRH can colocalize with vesicular glutamate transporter 2.

\section{Discussion}

A major finding of this study is that the puberty-initiating peptide KiSS-1 produces a remarkably strong and persistent activation of a unique subpopulation of GFP-glutamatergic cells that colocal- a1 KiSS-1 insensitive GnRH-GFP neuron
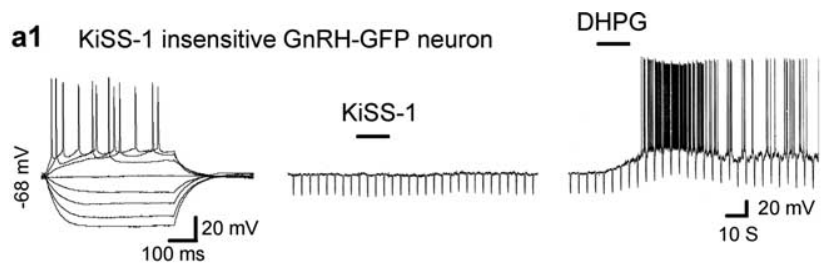

a2

KiSS-1 activated GnRH-GFP neuron
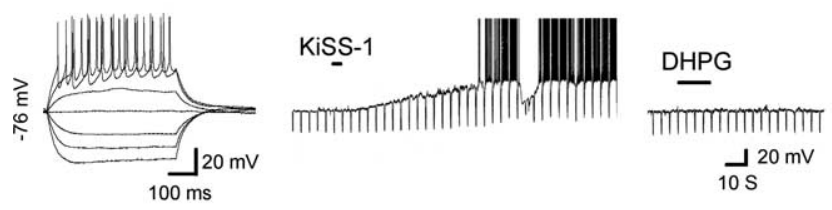

b1 KiSS-1 insensitive GnRH-GFP neuron
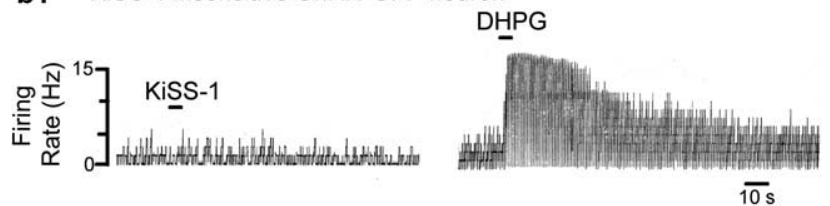

b2 KiSS-1 activated GnRH-GFP neuron
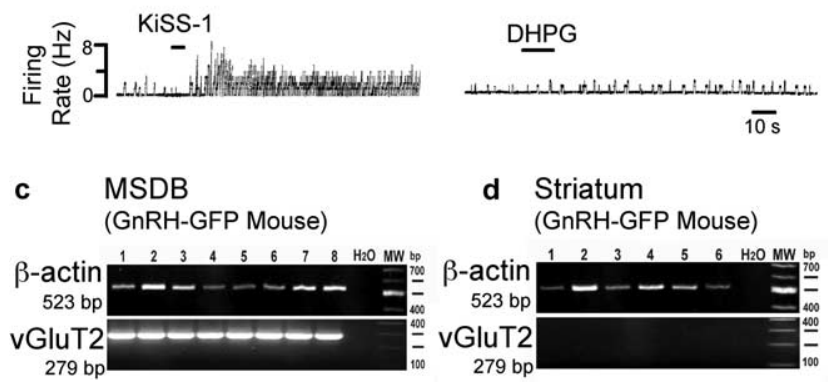

d Striatum (GnRH-GFP Mouse)

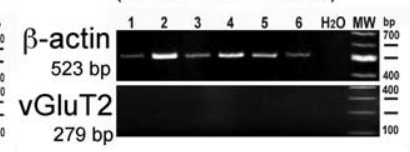

Figure 8. KiSS-1 and DHPG excite different MSDB GnRH-GFP neurons. a1, a2, Whole-cell patch-clamp recordings show two MSDB GnRH-GFP neurons. The neuron in a1 was strongly activated by a $15 \mathrm{~s}$ application of DHPG $(10 \mu \mathrm{m})$ but not by KiSS-1 $(1 \mu \mathrm{m})$; the neuron in $\boldsymbol{a} 2$ was unaffected by DHPG but was strongly activated by a $3 \mathrm{~s}$ application of $1 \mu \mathrm{m}$ KiSS-1. Note the associated increase in apparent input resistance that is similar to that seen in KiSS-1-activated MSDB vGluT2-GFP neurons. b1, b2, Two GnRH-GFP neurons recorded using the cell-attached mode of patch-clamp recording. The cell in $\boldsymbol{b} 1$ responded to DHPG but not to KiSS-1, whereas the cell in $\boldsymbol{b} \mathbf{2}$ had the opposite response. Thus, two types of MSDB GnRH-GFP can be differentiated based on their response to DHPG and KiSS-1. c, Single-cell RT-PCR studies in GnRH-GFP neurons. A different neuron is shown in each of the eight lanes. To demonstrate a successful harvest of a cell, $\beta$-actin was used. Note that 8 of 8 GnRH-GFP cells shown expressed vGluT2 mRNA, and another 4 of 4 were also positive. One control lane was used with water $\left(\mathrm{H}_{2} \mathrm{O}\right)$ instead of cell contents; as expected, this lane was negative. $\boldsymbol{d}$, For control purposes, we also harvested neurons from the neighboring striatum, where no vGluT2 is expected. All six cells expressed $\beta$-actin, but none of the cells showed vGluT2 expression.

ize GnRH in the rodent MSDB. This striking activation by KiSS-1 occurs both in prepubertal and pubertal male and female mice. In contrast, a second, nonoverlapping subpopulation of neurons, that can be differentiated physiologically on the basis of its response to a group I metabotropic glutamate receptor agonist, is insensitive to KiSS-1. Thus, we have for the first time identified two dramatically different subpopulations of GnRH neurons in the brain, one of which is exquisitely sensitive to KiSS-1 across reproductive development in both sexes. Given the central role of the KiSS-1-GPR54 system in activating the GnRH-gonadotropin cascade at the time of puberty and the subsequent maturation of reproductive organs leading to fertility, the discovery of two unique sets of GnRH neurons that differ in their sensitivity to KiSS-1 suggests that functional differences must exist between these two subpopulations. 


\section{Two physiologically distinct subpopulations of GnRH neurons}

In the present study, brief applications of very low nanomolar concentrations of KiSS-1 $(0.1 \mathrm{nM}$ to $1 \mu \mathrm{M}, 3-15 \mathrm{~s})$ produced a prolonged and profound concentration-dependent activation in a subpopulation of MSDB glutamatergic vGluT2-GFP neurons with an $\mathrm{EC}_{50}$ value of excitation of $\sim 10 \mathrm{nM}$, close to that reported for KiSS-1 binding to the GPR54 receptor (Kotani et al., 2001) and similar to that observed in recent electrophysiological studies on GnRH neurons (Liu et al., 2008; Zhang et al., 2008). Most significantly, these glutamatergic neurons colocalized $\mathrm{GnRH}$, accessed the peripheral vasculature, and were morphologically similar to GnRH-GFP neurons.

Our findings suggest two distinct subpopulations of $\mathrm{GnRH}$ neurons, based on the dramatic response of one subpopulation to KISS-1, and the complete absence of a KiSS-1 response in the other subpopulation. Could the lack of response to KISS-1 in some GnRH cells be an artifact, perhaps caused by washout of some critical substance during whole-cell recording or by a general inability of the cell to respond to excitatory stimuli? This seems unlikely for several reasons. First, all of the cells that showed no excitatory response to KISS-1 showed a strong excitatory response to DHPG, an agonist of group I metabotropic glutamate receptors. The mGluR receptors, similar to GRP54, are G-protein coupled, and similar to GPR54, depend on a parallel mechanisms of intracellular activation (Saugstad et al., 1998; Kotani et al., 2001). Second, cell-attached recordings, which leave the intracellular milieu unchanged, gave similar results as wholecell recordings, with some GnRH cells activated by KISS-1 but not by DHPG, and others activated by DHPG but not by KISS-1. No GnRH cells showed a response to both KISS-1 and DHPG. Third, we found the same two physiologically distinct subpopulations in two unrelated strains of transgenic mice, the vGluT2GFP mice and GnRH-GFP mice. Finally, the selective response to either KISS-1 or DHPG was regardless of the order of application of the two, suggesting that an initial response to KISS-1 did not block the subsequent response to metabotropic glutamate receptor agonists.

Other neurons within the MSDB nucleus, such as the DHPGactivated septohippocampal cholinergic, GABAergic, and glutamatergic neurons, also did not respond to KiSS-1. Previously, KiSS-1 has been suggested to transiently enhance evoked excitatory synaptic transmission and miniature synaptic currents in hippocampal granule cells without noticeable changes in resting membrane properties (Arai et al., 2005). Thus, between the various CNS neuronal subtypes tested, the DHPG-insensitive GnRH and glutamate colocalizing MSDB neurons are uniquely and exquisitely sensitive to the excitatory effects of KiSS-1.

Another defining property of the KiSS-1 response in GnRHcontaining $v$ GluT2-GFP neurons was its persistent nature that was readily detectable both with cell-attached and whole-cell recordings after even a short 3-5 s application of agonist. The persistent nature of the KiSS-1 response has also been noted in other studies, albeit after applying the agonist for minutes (Liu et al., 2008; Pielecka-Fortuna et al., 2008). However, the KiSS-1 response we see in these neurons is very different from that reported previously in preoptic GnRH neurons in which relatively little or no effect could be detected with whole-cell recording, and an action of KiSS-1 could only be found with perforated patch recording that preserves the intracellular milieu and retards loss of diffusible cytoplasmic molecules. Furthermore, in preoptic GnRH neurons, a longer application (minutes) was needed to generate an effect (Han et al., 2005) that requires only a few seconds in the $v G l u T 2-G n R H$ MSDB cells recorded here.

The KiSS-1 response in GnRH-colocalizing $v$ GluT2-GFP neurons is also remarkable in that it is readily seen in a similar proportion of neurons both in prepubertal and pubertal males and females. This is in contrast to the preoptic GnRH neurons, where only $44 \%$ of neurons responded to KiSS-1 before puberty; the percentage of KiSS-1-activated neurons doubled after puberty, although the magnitude of activation did not change across development. Thus, the DHPG-insensitive GnRH-colocalizing MSDB $v$ GluT2-GFP neurons respond to very brief, low nanomolar applications of KiSS-1 both during prepubertal and pubertal development using a mechanism that is robust even during whole-cell recording. The question of homogeneity in GnRH neurons has been raised previously based on electrophysiological variability and presence of estrogen receptor transcripts and response to estrogen (Sim et al., 2001; Abrahám and Herbison, 2005). Functionally, the vGluT2-colocalizing GnRH neurons that are responsive to KiSS-1 even during prepuberty may be relevant to precocious activation of the reproductive axis that is induced by exogenous kisspeptin in rodents (Navarro et al., 2004). Juvenile male monkeys also respond to repetitive activation of GPR54 by exogenous kisspeptin with a robust and sustained train of GnRH discharges and gonadotropin release akin to that which occurs during transition from a juvenile to pubertal state (Plant, 2006).

Mechanistically, KiSS-1 excitation of GnRH-containing MSDB vGluT2-GFP neurons occurs via a direct postsynaptic mechanism that reverses near $E_{\mathrm{k}}$ and involves a closing of $\mathrm{Ba}^{2+}$ sensitive $\mathrm{K}^{+}$channels; a reversal near $E_{\mathrm{k}}$ and involvement of $\mathrm{K}^{+}$ channels has recently been noted for $\mathrm{GnRH}$ neurons (Liu et al., 2008; Pielecka-Fortuna et al., 2008). Whereas the latter study noted the exclusive involvement of $\mathrm{K}^{+}$channels, Liu et al. (2008) also observed a second mechanism in preoptic GnRH neurons that involves an exclusive or an additional opening of cationic channels. An involvement of canonical transient receptor potential-like cationic channels was also noted in another study on preoptic GnRH neurons (Zhang et al., 2008). Our findings are consistent with previous studies in that they support the closure of a $\mathrm{K}^{+}$channel in mediating the excitatory effects of KiSS-1. KiSS-1 excitation in GnRH-colocalizing vGluT2-GFP neurons is different from hippocampal granule cells in that it is present after buffering internal calcium (Arai et al., 2005).

Another feature of the KiSS-1 effect in GnRH colocalizing MSDB $v$ GluT2-GFP neurons is its apparent desensitization even at low nM concentrations, wherein a second application of KiSS-1 yields little or no response, a similar desensitization has been noted in previous studies (Liu et al., 2008; Pielecka-Fortuna et al., 2008).

\section{Glutamate, $\mathrm{GnRH}$, and reproductive development}

A key finding of this study is the observation that of all CNS neurons tested, KiSS-1 by far appeared to have the strongest effects on a subpopulation of GnRH colocalizing vGluT2 MSDB neurons. Based on our immunolabeling and single-cell RT-PCR data, most of the kisspeptin responding neurons we recorded probably contained both GnRH and vGluT2. Because we did not demonstrate colocalization of GnRH and $v$ GluT2-GFP in all cells recorded, there is the possibility that a minority of $v G l u T 2-G F P$ KiSS-1-responding cells in the MSDB may not contain GnRH. Thus, although in the present study GnRH mRNA was found in 6 of 6 KiSS-1-activated $v$ GluT2-GFP neurons, and vGluT2 mRNA was detectable in 12 of 12 KiSS-1-activated GnRH-GFP neurons, 
it is conceivable that all septal KiSS-1-activated $v$ GluT2-GFP neurons may not colocalize GnRH. Similarly, all septal KiSS-1activated GnRH-GFP neurons may also not colocalize vGluT2 mRNA. Nevertheless, our data are consistent with the existence of at least a subpopulation of vGluT2 and GnRH colocalizing KiSS-1-sensitive septal neurons.

Functionally, the presence of vGluT2 confers a glutamatergic phenotype to neurons; thus, KiSS-1 activation could corelease glutamate and $\mathrm{GnRH}$ into the pituitary portal blood system of the median eminence. In the median eminence, glutamate enhances GnRH release (Kawakami et al., 1998). Colocalization of vGluT2 in GnRH neurons has been noted previously (Hrabovszky et al., 2004). The present study is the first to record from GnRH neurons that were also shown to express a glutamate vesicular transporter, suggesting use of glutamate as a fast transmitter and demonstrate the remarkable sensitivity to KiSS-1 that spans across prepubertal and postpubertal stages of development in both sexes.

GnRH neurons form a small diffuse population of somewhat less than a thousand cells in the mouse hypothalamus and basal forebrain that orchestrate and control reproductive development and fertility by integrating multiple inputs from thousands of neurons located in multiple brain areas. In turn, GnRH neurons transmit signals not only to the median eminence but also to a large number of neurons in an estimated 34 brain areas associated with different functions that include odor and pheromone processing, sexual behavior, appetite, and defensive behavior (Merchenthaler et al., 1984; Jennes, 1991; Boehm et al., 2005; Yoon et al., 2005). In this regard, it is tempting to speculate that different subpopulations of GnRH neurons that we identify may subserve different functions by virtue of potentially different inputs and outputs.

In conclusion, in this study we suggest the existence of two physiologically distinct subpopulations of GnRH neurons that are distinguishable based on their differential sensitivity to kisspeptin or to a metabotropic glutamate receptor agonist. The colocalization of glutamate and GnRH in MSDB neurons suggests that glutamate could potentially act as a fast transmitter at $\mathrm{GnRH}$ central synapses and may enhance release of GnRH from axons in the median eminence.

\section{References}

Abrahám IM, Herbison AE (2005) Major sex differences in nongenomic estrogen actions on intracellular signaling in mouse brain in vivo. Neuroscience 131:945-951.

Alreja M, Liu W (1996) Noradrenaline induces IPSCs in rat medial septal/ diagonal band neurons: involvement of septohippocampal GABAergic neurons. J Physiol 494:201-215.

Alreja M, Wu M, Liu W, Atkins JB, Leranth C, Shanabrough M (2000) Muscarinic tone sustains impulse flow in the septohippocampal GABA but not cholinergic pathway: implications for learning and memory. J Neurosci 20:8103-8110.

Arai AC, Xia YF, Suzuki E, Kessler M, Civelli O, Nothacker HP (2005) Cancer metastasis-suppressing peptide metastin upregulates excitatory synaptic transmission in hippocampal dentate granule cells. J Neurophysiol 94:3648-3652.

Boehm U, Zou Z, Buck LB (2005) Feedback loops link odor and pheromone signaling with reproduction. Cell 123:683-695.

Brailoiu GC, Dun SL, Ohsawa M, Yin D, Yang J, Chang JK, Brailoiu E, Dun NJ (2005) KiSS-1 expression and metastin-like immunoreactivity in the rat brain. J Comp Neurol 481:314-329.

Campbell RE, Han SK, Herbison AE (2005) Biocytin filling of adult gonadotropin-releasing hormone neurons in situ reveals extensive, spiny, dendritic processes. Endocrinology 146:1163-1169.

Clarkson J, Herbison AE (2006) Postnatal development of kisspeptin neurons in mouse hypothalamus; sexual dimorphism and projections to gonadotropin-releasing hormone neurons. Endocrinology 147: $5817-5825$.

Cottrell EC, Campbell RE, Han SK, Herbison AE (2006) Postnatal remodelling of dendritic structure and spine density in gonadotropinreleasing hormone (GnRH) neurons. Endocrinology 147:3652-3661.

de Roux N, Genin E, Carel JC, Matsuda F, Chaussain JL, Milgrom E (2003) Hypogonadotropic hypogonadism due to loss of function of the KiSS1derived peptide receptor GPR54. Proc Natl Acad Sci USA 100:10972-10976.

Franceschini I, Lomet D, Cateau M, Delsol G, Tillet Y, Caraty A (2006) Kisspeptin immunoreactive cells of the ovine preoptic area and arcuate nucleus co-express estrogen receptor alpha. Neurosci Lett 401:225-230.

Fremeau RT Jr, Troyer MD, Pahner I, Nygaard GO, Tran CH, Reimer RJ, Bellocchio EE, Fortin D, Storm-Mathisen J, Edwards RH (2001) The expression of vesicular glutamate transporters defines two classes of excitatory synapse. Neuron 31:247-260.

Fu LY, van den Pol AN (2008) Agouti-related peptide and MC3/4 receptor agonists both inhibit excitatory hypothalamic ventromedial nucleus neurons. J Neurosci 28:5433-5449.

Funes S, Hedrick JA, Vassileva G, Markowitz L, Abbondanzo S, Golovko A, Yang S, Monsma FJ, Gustafson EL (2003) The KiSS-1 receptor GPR54 is essential for the development of the murine reproductive system. Biochem Biophys Res Commun 312:1357-1363.

Gottsch ML, Cunningham MJ, Smith JT, Popa SM, Acohido BV, Crowley WF, Seminara S, Clifton DK, Steiner RA (2004) A role for kisspeptins in the regulation of gonadotropin secretion in the mouse. Endocrinology 145:4073-4077.

Han SK, Todman MG, Herbison AE (2004) Endogenous GABA release inhibits the firing of adult gonadotropin-releasing hormone neurons. Endocrinology 145:495-499.

Han SK, Gottsch ML, Lee KJ, Popa SM, Smith JT, Jakawich SK, Clifton DK, Steiner RA, Herbison AE (2005) Activation of gonadotropin-releasing hormone neurons by kisspeptin as a neuroendocrine switch for the onset of puberty. J Neurosci 25:11349-11356.

Härtig W, Seeger J, Naumann T, Brauer K, Brückner G (1998) Selective in vivo fluorescence labelling of cholinergic neurons containing p75(NTR) in the rat basal forebrain. Brain Res 808:155-165.

Hrabovszky E, Turi GF, Kalló I, Liposits Z (2004) Expression of vesicular glutamate transporter-2 in gonadotropin-releasing hormone neurons of the adult male rat. Endocrinology 145:4018-4021.

Huang H, Ghosh P, van den Pol AN (2006) Prefrontal cortex-projecting glutamatergic thalamic paraventricular nucleus-excited by hypocretin: a feedforward circuit that may enhance cognitive arousal. J Neurophysiol 95:1656-1668.

Jennes L (1991) Dual projections of gonadotropin releasing hormone containing neurons to the interpeduncular nucleus and to the vasculature in the female rat. Brain Res 545:329-333.

Kang L, Routh VH, Kuzhikandathil EV, Gaspers LD, Levin BE (2004) Physiological and molecular characteristics of rat hypothalamic ventromedial nucleus glucosensing neurons. Diabetes 53:549-559.

Kawakami S, Ichikawa M, Murahashi K, Hirunagi K, Tsukamura H, Maeda K (1998) Excitatory amino acids act on the median eminence nerve terminals to induce gonadotropin-releasing hormone release in female rats. Gen Comp Endocrinol 112:372-382.

Kinoshita M, Tsukamura H, Adachi S, Matsui H, Uenoyama Y, Iwata K, Yamada S, Inoue K, Ohtaki T, Matsumoto H, Maeda K (2005) Involvement of central metastin in the regulation of preovulatory luteinizing hormone surge and estrous cyclicity in female rats. Endocrinology 146:4431-4436.

Kotani M, Detheux M, Vandenbogaerde A, Communi D, Vanderwinden JM, Le Poul E, Brézillon S, Tyldesley R, Suarez-Huerta N, Vandeput F, Blanpain C, Schiffmann SN, Vassart G, Parmentier M (2001) The metastasis suppressor gene KiSS-1 encodes kisspeptins, the natural ligands of the orphan G protein-coupled receptor GPR54. J Biol Chem 276:34631-34636.

Lee JH, Welch DR (1997) Suppression of metastasis in human breast carcinoma MDA-MB-435 cells after transfection with the metastasis suppressor gene, KiSS-1. Cancer Res 57:2384-2387.

Lee JH, Miele ME, Hicks DJ, Phillips KK, Trent JM, Weissman BE, Welch DR (1996) KiSS-1, a novel human malignant melanoma metastasissuppressor gene. J Natl Cancer Inst 88:1731-1737.

Liu X, Lee K, Herbison AE (2008) Kisspeptin excites gonadotropin- 
releasing hormone $(\mathrm{GnRH})$ neurons through a phospholipase $\mathrm{C} /$ calcium-dependent pathway regulating multiple ion channels. Endocrinology.

Livne I, Gibson MJ, Silverman AJ (1993) Gonadotropin-releasing hormone $(\mathrm{GnRH})$ neurons in the hypogonadal mouse elaborate normal projections despite their biosynthetic deficiency. Neurosci Lett 151:229-233.

Merchenthaler I, Görcs T, Sétáló G, Petrusz P, Flerkó B (1984) Gonadotropin-releasing hormone ( $\mathrm{GnRH})$ neurons and pathways in the rat brain. Cell Tissue Res 237:15-29.

Merchenthaler I, Culler MD, Petrusz P, Flerkó B, Negro-Vilar A (1989a) Immunocytochemical localization of the gonadotropin-releasing hormone-associated peptide portion of the LHRH precursor in the hypothalamus and extrahypothalamic regions of the rat central nervous system. Cell Tissue Res 255:5-14.

Merchenthaler I, Setalo G, Csontos C, Petrusz P, Flerko B, Negro-Vilar A (1989b) Combined retrograde tracing and immunocytochemical identification of luteinizing hormone-releasing hormone- and somatostatincontaining neurons projecting to the median eminence of the rat. Endocrinology 125:2812-2821.

Morris NP, Harris SJ, Henderson Z (1999) Parvalbumin-immunoreactive, fast-spiking neurons in the medial septum/diagonal band complex of the rat: intracellular recordings in vitro. Neuroscience 92:589-600.

Muir AI, Chamberlain L, Elshourbagy NA, Michalovich D, Moore DJ, Calamari A, Szekeres PG, Sarau HM, Chambers JK, Murdock P, Steplewski K, Shabon U, Miller JE, Middleton SE, Darker JG, Larminie CG, Wilson S, Bergsma DJ, Emson P, Faull R, et al. (2001) AXOR12, a novel human G protein-coupled receptor, activated by the peptide KiSS-1. J Biol Chem 276:28969-28975.

Navarro VM, Fernández-Fernández R, Castellano JM, Roa J, Mayen A, Barreiro ML, Gaytan F, Aguilar E, Pinilla L, Dieguez C, Tena-Sempere M (2004) Advanced vaginal opening and precocious activation of the reproductive axis by KiSS-1 peptide, the endogenous ligand of GPR54. J Physiol 561:379-386.

Ohtaki T, Shintani Y, Honda S, Matsumoto H, Hori A, Kanehashi K, Terao Y, Kumano S, Takatsu Y, Masuda Y, Ishibashi Y, Watanabe T, Asada M, Yamada T, Suenaga M, Kitada C, Usuki S, Kurokawa T, Onda H, Nishimura O, et al. (2001) Metastasis suppressor gene KiSS-1 encodes peptide ligand of a G-protein-coupled receptor. Nature 411:613-617.

Parducz A, Zsarnovszky A, Naftolin F, Horvath TL (2003) Estradiol affects axo-somatic contacts of neuroendocrine cells in the arcuate nucleus of adult rats. Neuroscience 117:791-794.

Pielecka-Fortuna J, Chu Z, Moenter SM (2008) Kisspeptin acts directly and indirectly to increase gonadotropin-releasing hormone neuron activity and its effects are modulated by estradiol. Endocrinology 149:1979-1986.

Plant TM (2006) The role of KiSS-1 in the regulation of puberty in higher primates. Eur J Endocrinol 155 [Suppl 1]:S11-S16.

Plant TM, Ramaswamy S, Dipietro MJ (2006) Repetitive activation of hypothalamic $\mathrm{G}$ protein-coupled receptor 54 with intravenous pulses of kisspeptin in the juvenile monkey (Macaca mulatta) elicits a sustained train of gonadotropin-releasing hormone discharges. Endocrinology 147:1007-1013.

Popa SM, Clifton DK, Steiner RA (2005) A KiSS to remember. Trends Endocrinol Metab 16:249-250.

Saugstad JA, Marino MJ, Folk JA, Hepler JR, Conn PJ (1998) RGS4 inhibits signaling by group I metabotropic glutamate receptors. J Neurosci 18:905-913.

Seminara SB, Messager S, Chatzidaki EE, Thresher RR, Acierno JS Jr, Shagoury JK, Bo-Abbas Y, Kuohung W, Schwinof KM, Hendrick AG, Zahn D, Dixon J, Kaiser UB, Slaugenhaupt SA, Gusella JF, O'Rahilly S, Carlton MB, Crowley WF Jr, Aparicio SA, Colledge WH (2003) The GPR54 gene as a regulator of puberty. $\mathrm{N}$ Engl J Med 349:1614-1627.
Semple RK, Achermann JC, Ellery J, Farooqi IS, Karet FE, Stanhope RG, O'rahilly S, Aparicio SA (2005) Two novel missense mutations in g protein-coupled receptor 54 in a patient with hypogonadotropic hypogonadism. J Clin Endocrinol Metab 90:1849-1855.

Sim JA, Skynner MJ, Herbison AE (2001) Heterogeneity in the basic membrane properties of postnatal gonadotropin-releasing hormone neurons in the mouse. J Neurosci 21:1067-1075.

Smith JT, Cunningham MJ, Rissman EF, Clifton DK, Steiner RA (2005) Regulation of Kiss1 gene expression in the brain of the female mouse. Endocrinology 146:3686-3692.

Spergel DJ, Krüth U, Hanley DF, Sprengel R, Seeburg PH (1999) GABAand glutamate-activated channels in green fluorescent protein-tagged gonadotropin-releasing hormone neurons in transgenic mice. J Neurosci 19:2037-2050.

Suter KJ, Song WJ, Sampson TL, Wuarin JP, Saunders JT, Dudek FE, Moenter SM (2000) Genetic targeting of green fluorescent protein to gonadotropin-releasing hormone neurons: characterization of whole-cell electrophysiological properties and morphology. Endocrinology 141:412-419.

Tena-Sempere M (2006) KiSS- 1 and reproduction: focus on its role in the metabolic regulation of fertility. Neuroendocrinology 83:275-281.

Thompson EL, Patterson M, Murphy KG, Smith KL, Dhillo WS, Todd JF, Ghatei MA, Bloom SR (2004) Central and peripheral administration of kisspeptin-10 stimulates the hypothalamic-pituitary-gonadal axis. J Neuroendocrinol 16:850-858.

Todman MG, Han SK, Herbison AE (2005) Profiling neurotransmitter receptor expression in mouse gonadotropin-releasing hormone neurons using green fluorescent protein-promoter transgenics and microarrays. Neuroscience 132:703-712.

Tsien RY (1980) New calcium indicators and buffers with high selectivity against magnesium and protons: design, synthesis, and properties of prototype structures. Biochemistry 19:2396-2404.

Weiss ML, Cobbett P (1992) Intravenous injection of Evans Blue labels magnocellular neuroendocrine cells of the rat supraoptic nucleus in situ and after dissociation. Neuroscience 48:383-395.

Witkin JW (1990) Access of luteinizing hormone-releasing hormone neurons to the vasculature in the rat. Neuroscience 37:501-506.

Wu M, Shanabrough M, Leranth C, Alreja M (2000) Cholinergic excitation of septohippocampal GABA but not cholinergic neurons: implications for learning and memory. J Neurosci 20:3900-3908.

Wu M, Zhang Z, Leranth C, Xu C, van den Pol AN, Alreja M (2002) Hypocretin increases impulse flow in the septohippocampal GABAergic pathway: implications for arousal via a mechanism of hippocampal disinhibition. J Neurosci 22:7754-7765.

Wu M, Hajszan T, Leranth C, Alreja M (2003) Nicotine recruits a local glutamatergic circuit to excite septohippocampal GABAergic neurons. Eur J Neurosci 18:1155-1168.

Wu M, Hajszan T, Xu C, Leranth C, Alreja M (2004a) Group I metabotropic glutamate receptor activation produces a direct excitation of identified septohippocampal cholinergic neurons. J Neurophysiol 92:1216-1225.

Wu M, Zaborszky L, Hajszan T, van den Pol AN, Alreja M (2004b) Hypocretin/orexin innervation and excitation of identified septohippocampal cholinergic neurons. J Neurosci 24:3527-3536.

Xu C, Michelsen KA, Wu M, Morozova E, Panula P, Alreja M (2004) Histamine innervation and activation of septohippocampal GABAergic neurones: involvement of local ACh release. J Physiol 561:657-670.

Yoon H, Enquist LW, Dulac C (2005) Olfactory inputs to hypothalamic neurons controlling reproduction and fertility. Cell 123:669-682.

Zhang C, Roepke TA, Kelly MJ, Rønnekleiv OK (2008) Kisspeptin depolarizes gonadotropin-releasing hormone neurons through activation of TRPC-like cationic channels. J Neurosci 28:4423-4434. 